Fifth International Conference on Sustainable Construction Materials and Technologies. http://www.claisse.info/Proceedings.htm

\title{
CLAY-BURNT COARSE AGGREGATE: PRODUCTION AND UTILIZATION IN CONCRETE
}

\author{
Tarek U. Mohammed ${ }^{1}$, Aziz H. Mahmood ${ }^{2}$, Syed S. Ahmed ${ }^{3}$, and Mosabbir Pasha ${ }^{4}$ \\ ${ }^{1}$ Department of Civil and Environmental Engineering, Islamic University of \\ Technology(IUT), Gazipur 1704, Bangladesh,Email: tarek@iut-dhaka.edu \\ ${ }^{2}$ Centre for Infrastructure Engineering and Safety (CIES), School of Civil and \\ Environmental Engineering, The University of New South Wales (UNSW), Sydney \\ 2052, Australia, Email: azizhasanmahmood@unsw.edu.au \\ ${ }^{3}$ Independent Consultant, Bangladesh, Email: engsyedahmed@gmail.com \\ ${ }^{4}$ Centre for Transport Strategy, School of Civil Engineering, University of Queensland, \\ Brisbane 4072, Australia, Email: 〈m.pasha@uq.edu.au>
}

\begin{abstract}
Scarcity of natural aggregates in Bangladesh has led the construction industry to rely prominently on crushed brick coarse aggregates. The crushing procedure involves material waste and lacks means to control the grading, which results in poor quality concrete. These drawbacks could be addressed if graded aggregates could be made by burning clay. With this background, suitable soil was sampled, molded and burnt at high temperatures $\left(850^{\circ} \mathrm{C}, 900^{\circ} \mathrm{C}\right.$, and $\left.950^{\circ} \mathrm{C}\right)$ to make clay-burnt coarse aggregates (CBCA) of different sizes $(20 \mathrm{~mm}, 15 \mathrm{~mm}, 10 \mathrm{~mm}$ and $5 \mathrm{~mm})$. Physical properties of the aggregates were investigated and cylindrical concrete specimens were made with both CBCA and other locally available aggregates. Aggregates produced at $950^{\circ} \mathrm{C}$ showed better aggregate properties compared to first class brick aggregates. CBCA made concrete resulted in higher compressive strength compared to stone and brick aggregates. Direct production of $\mathrm{CBCA}$ has the potential to enhance overall construction quality in Bangladesh.
\end{abstract}

Keywords: Clay burnt aggregate, concrete, coarse aggregates.

\section{INTRODUCTION}

The demand of concrete is increasing day by day due to the necessity for development of infrastructures in parallel with growing population as well as economic development. Concrete consumption in the world is estimated at two and a half tons per capita per year (equivalent to 17.5 billion tons for 7 billion populations in the world) (CAMBUREAU 2008; Mehta 2009). To make this huge volume of concrete 2.62 billion tons of cement, 13.12 billion tons of aggregate, and 1.75 billion tons of water are necessary. Two billion tons of aggregates are produced each year in the United 
States. Production of aggregate is expected to exceed 2.5 billion tons per year by the year 2020 (US Department of Transportation Federal Highway Administration 2004).The consumption is also booming in developing countries like Bangladesh. Bangladesh is one of the emerging developing countries, consuming 90 million tons of concrete every year (IDLC Finance Limited 2011). To make such a huge volume of concrete, a huge amount of aggregate is required. Generally, aggregates are collected by cutting mountains or breaking river gravels or boulders, or by breaking clay bricks. But, due to the shortage of gravels and boulders in Bangladesh, clay brick aggregates are commonly used in construction works. Unfortunately, most of these aggregates are of inferior in quality, poorly graded and flaky shaped. Coarse aggregates produced by crushing bricks manually or by power crusher also produce a significant amount of waste (aggregate passing through \#4 sieve). To remove the finer part from the aggregate screening is necessary and it requires more labor. Making aggregates by crushing bricks also produces micro cracks in aggregates which affects the strength of concrete. Also poor gradation and low quality coarse aggregate used in construction works reduce the strength and durability of concrete in the long run. On the other hand, for storage of aggregate a large space is necessary. Due to the lack of proper storage facilities, the materials are stored in open field or on the roadside and thus impurities such as tree leaves, waste papers, waste clothes, waste polythene are mixed with the aggregate. When coarse aggregate are stored on the roadside, it also causes hindrance to traffic and public movement. Therefore, it is indispensable to invent an alternative method for production of coarse aggregate which may solve the problems related to coarse aggregate. If earthen aggregate is possible to make by burning directly in an automated machine and supplied to the construction sites in bags with proper grading, a radical change will occur in prevailing construction system of the country. It will improve the quality of construction works and will contribute to the sustainable development of construction materials in Bangladesh (Mohammed 2011, Mohammed 2015). With this background, the present research has been planned.

\section{EXPERIMENTAL METHOD}

\section{Soil Properties}

For making clay-burnt coarse aggregate, a suitabe fine soil sample was collected. The physical properties of the soil were tested. The liquid limit and plastic limit of the soil sample were $52.52 \%$ and $20.22 \%$ respectively. The \% finer through the \#100 sieve was $97 \%$.

\section{Production of Clay-Burnt Coarse Aggregate}

The flow chart of aggregate production process is shown in Fig. 1. The production process of aggregate includes collection of soil samples, making paste of soil, forming blocks, giving required shape and size of aggregate, drying, and burning. The soil block was pushed at one end of aggregate making device and passed it through a wire net at the other end with triangular opening of particular dimension $(5 \mathrm{~mm}, 10 \mathrm{~mm}, 15 \mathrm{~mm}$, and $20 \mathrm{~mm}$ ) and then cut it vertically after passing a certain distance $(5 \mathrm{~mm}, 10 \mathrm{~mm}$, $15 \mathrm{~mm}$, and $20 \mathrm{~mm}$ ). The wet aggregate was air dried to reduce water content to $3.2 \%$ 
and then burned it in an oven. The burning temperatures were $850^{\circ} \mathrm{C}, 900^{\circ} \mathrm{C}$, and $950^{\circ} \mathrm{C}$. The burning time was 6 hours. The size of aggregate was $20 \mathrm{~mm}, 15 \mathrm{~mm}, 10$ $\mathrm{mm}$, and $5 \mathrm{~mm}$.

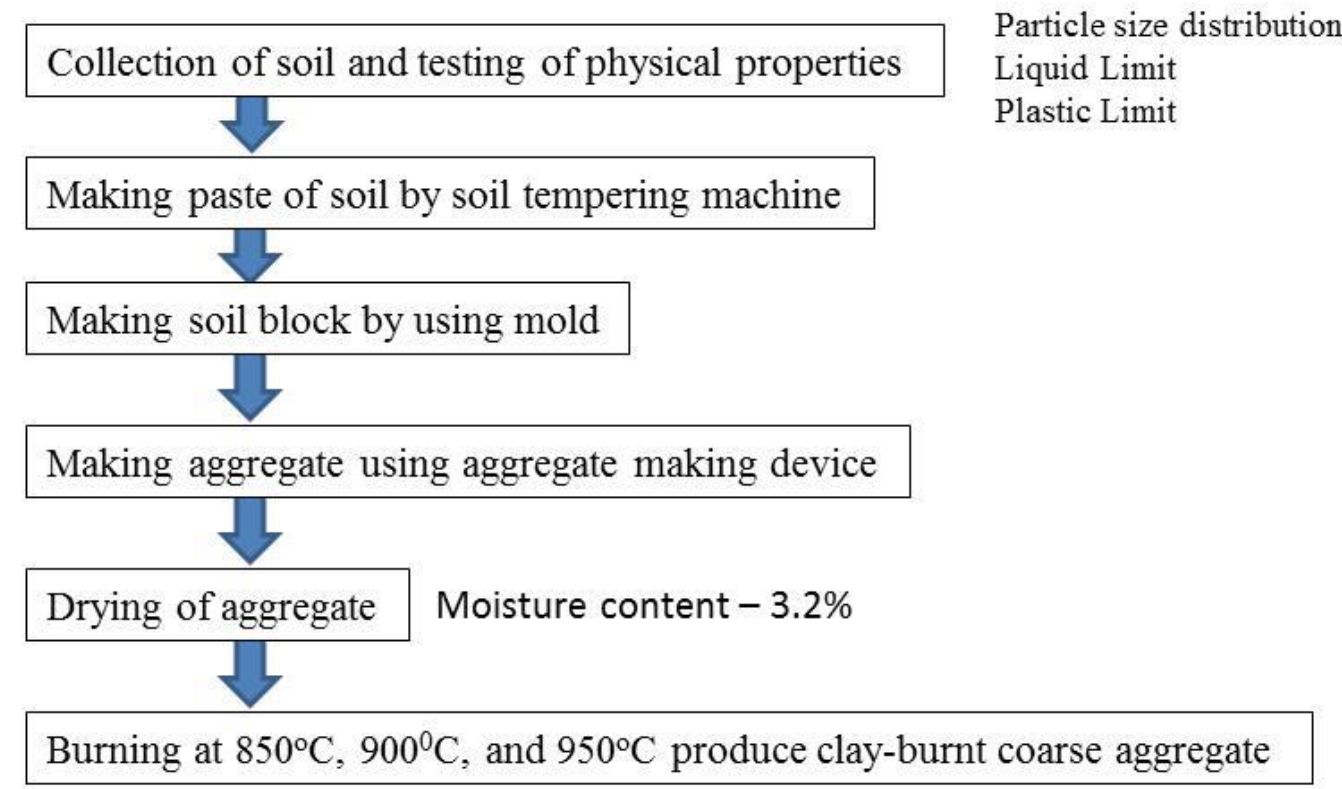

Fig. 1. Flow chart of clay-burnt coarse aggregate production

Table 1. Mixture Proportion of Concrete

\begin{tabular}{|c|c|c|c|c|c|c|c|}
\hline \multirow{2}{*}{$\begin{array}{l}\text { Sl. } \\
\text { No. }\end{array}$} & \multirow[t]{2}{*}{ Cases Investigated } & \multirow[t]{2}{*}{ W/C } & \multirow[t]{2}{*}{$\mathbf{s} / \mathbf{a}$} & \multicolumn{4}{|c|}{ Unit Content $\left(\mathrm{kg} / \mathrm{m}^{3}\right)$} \\
\hline & & & & $\begin{array}{l}\text { Cement } \\
\text { (C) }\end{array}$ & $\begin{array}{c}\text { Water } \\
(\mathbf{W})\end{array}$ & $\begin{array}{c}\text { Fine } \\
\text { Aggregate }\end{array}$ & $\begin{array}{c}\text { Coarse } \\
\text { Aggregate }\end{array}$ \\
\hline 1 & CBCACC340WC55 & 0.55 & 0.40 & 340 & 187.0 & 711 & 902 \\
\hline 2 & CBCACC400WC45 & 0.45 & 0.44 & 400 & 180.0 & 768 & 827 \\
\hline 3 & CBCACC450WC45 & 0.45 & 0.45 & 450 & 202.5 & 723 & 779 \\
\hline 4 & PBCC340WC55 & 0.55 & 0.47 & 340 & 187.0 & 782 & 764 \\
\hline 5 & CSCC340WC55 & 0.55 & 0.46 & 340 & 187.0 & 781 & 956 \\
\hline 6 & FBCC340WC55 & 0.55 & 0.44 & 340 & 187 & 787.87 & 841.74 \\
\hline 7 & FBCC340WC45 & 0.45 & 0.44 & 340 & 153 & 826.93 & 883.74 \\
\hline 8 & SBCC340WC55 & 0.55 & 0.47 & 340 & 187 & 826.8 & 803.5 \\
\hline 9 & SBCC340WC45 & 0.45 & 0.47 & 340 & 153 & 826.93 & 803.4 \\
\hline 10 & TBCC340WC55 & 0.55 & 0.47 & 340 & 187 & 826.8 & 803.5 \\
\hline 11 & TBCC340WC45 & 0.45 & 0.47 & 340 & 153 & 826.93 & 803.4 \\
\hline 12 & FBCC400WC40 & 0.40 & 0.32 & 400 & 160 & 790.47 & 831.93 \\
\hline 13 & CSCC400WC40 & 0.40 & 0.49 & 400 & 160 & 790.47 & 851.27 \\
\hline
\end{tabular}


Concrete samples were made by using clay- burnt coarse aggregate burnt at $950^{\circ} \mathrm{C}$ as the quality of aggregate was better at this burning temperature compared to the other burning temperatures $\left(850^{\circ} \mathrm{C}\right.$ and $\left.900^{\circ} \mathrm{C}\right)$. Concrete cylinders of size $100 \mathrm{~mm}$ in diameter and $200 \mathrm{~mm}$ in height were made. A total of 3 cases of clay-burnt coarse aggregate (CBCA) were investigated which are shown in Table 1.For comparison with CBCA, picked brick $(\mathrm{PB}), 1^{\text {st }}$ class brick $(\mathrm{FB}), 2^{\text {nd }}$ class brick $(\mathrm{SB}), 3^{\text {rd }}$ class brick $(\mathrm{TB})$ and crushed stone (CS) were also investigated. Cement contents were 340, 400, and $450 \mathrm{~kg} / \mathrm{m}^{3}$ and $\mathrm{W} / \mathrm{C}$ ratios were $0.55,0.45$. Detailed mixture proportions of different cases are summarized in Table 1.

\section{Mixing, Casting, and Curing of Concrete}

The grading of aggregates (coarse and fine) was controlled as per ASTM standards (ASTM C33 2003). Saturated surface dry aggregates was used for making specimens. Concrete was mixed in a mixture machine and the steel molds were used for making specimens. After casting, the molds were covered by a polythene sheet to avoid evaporation of water from concrete. After one day, the samples were de-molded from the mold and then the specimens were submerged under water for curing.

\section{Testing}

The coarse aggregates were tested for unit weight, absorption capacity, abrasion resistance, aggregate crushing value, and aggregate impact value as per ASTM standards. The concrete specimens were tested for compressive strength, tensile strength, and Young's modulus of concrete at 7, 14, and 28 days as per ASTM standard. Also, workability of fresh concrete was measured by slump cone immediately after mixing of concrete.

\section{RESULTS AND DISCUSSIONS}

\section{Physical Properties of Clay-Burnt Coarse Aggregate}

The unit weight, absorption capacity, wear value, aggregate crushing value, aggregate impact value of clay-burnt coarse aggregate (CBCA) with the variation of burning temperature are shown in Fig. $2 \sim$ Fig. 7 respectively. For burning temperature of $950^{\circ} \mathrm{C}$, the unit weight of CBCA is slightly higher than picked brick (PB), first class brick (FB), second class brick (SB), and third class brick (TB), but it is lower than crushed stone (CS).Absorption capacity of clay-burnt coarse aggregate is decreased with the increase of burning temperature (Fig. 3). It indicates that CBCA becomes less permeable with the increase of burning temperature. The absorption capacity of CBCA is lower compared to $\mathrm{FB}, \mathrm{SB}$, and $\mathrm{TB}$, and becomes closer to $\mathrm{PB}$ at higher burning temperature. The abrasion resistance of $\mathrm{CBCA}$ is increased with the increase of burning temperature. It indicates that stronger aggregates are produced with increase of burning temperature. The abrasion resistance (wear value) of CBCA is lower than FB, SB, and TB but higher than PB and CS. Same as wear value, it is found that aggregate crushing value (ACV) and aggregate impact value (AIV) of CBCA are reduced with the increase of burning temperature. Specific gravity of CBCA is reduced with the increase of 
burning temperature. The results indicate that by increasing burning temperature over $950^{\circ} \mathrm{C}$, it will be possible to produce lighter CBCA.

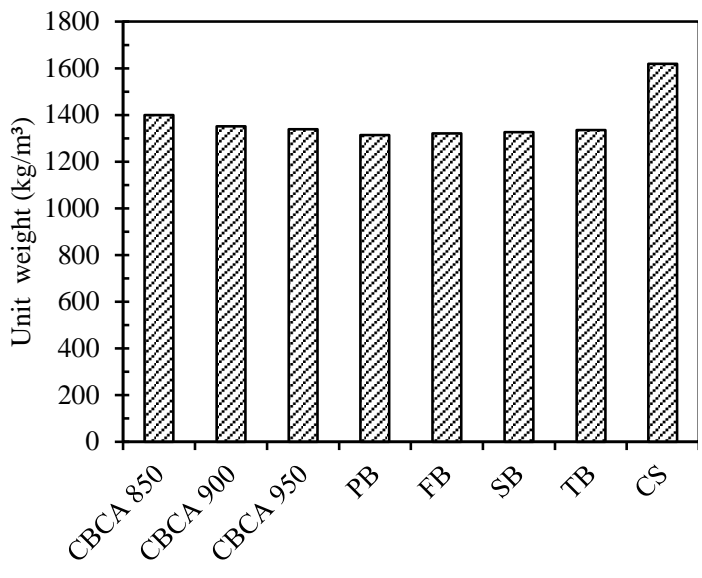

Fig. 2 Unit weight of different types of coarse aggregates

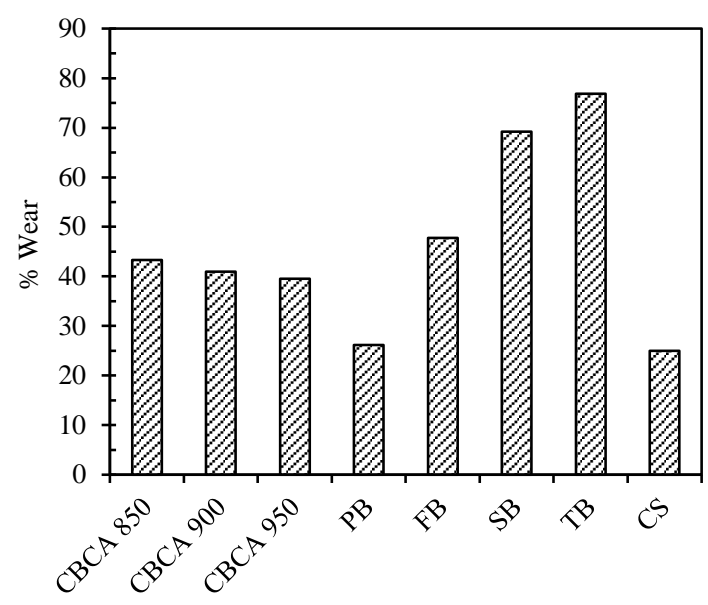

Fig. 4 Abrasion resistance of different types of coarse aggregates

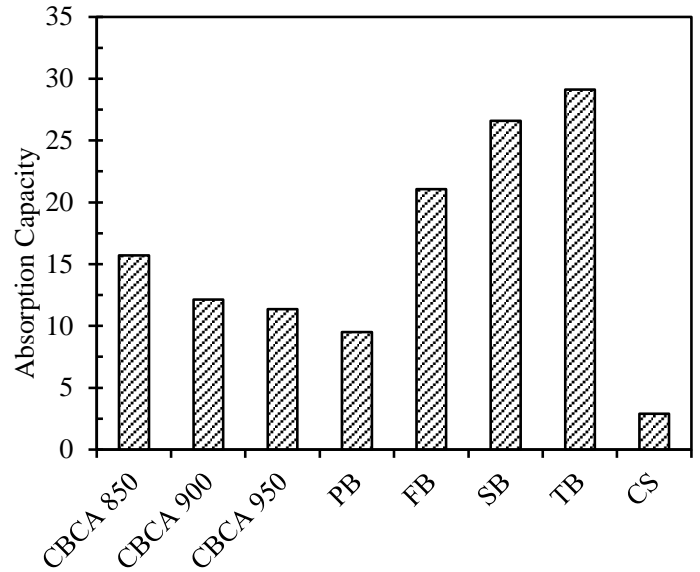

Fig. 3 Absorption capacity of different types of coarse aggregates

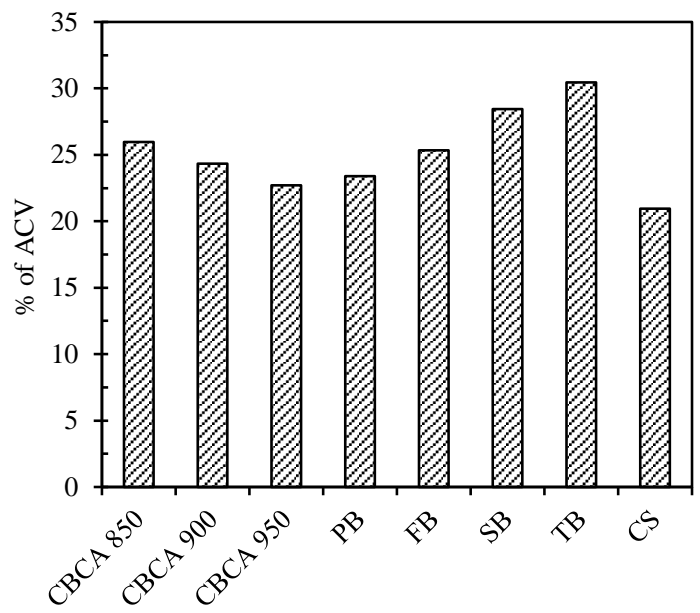

Fig. 5 Aggregate crushing values of different types of coarse aggregates

\section{Properties of Fresh Concrete}

The variation of workability of concrete for different aggregates is shown in Fig. 8. With the increase of cement content, the workability of CBCA is increased. For same $\mathrm{W} / \mathrm{C}$ and cement content, lower workability of concrete is found for CBCA compared to $\mathrm{PB}, \mathrm{FB}$, and $\mathrm{CS}$. It is expected due to the sharp angularity of CBCA compared to other aggregates. 


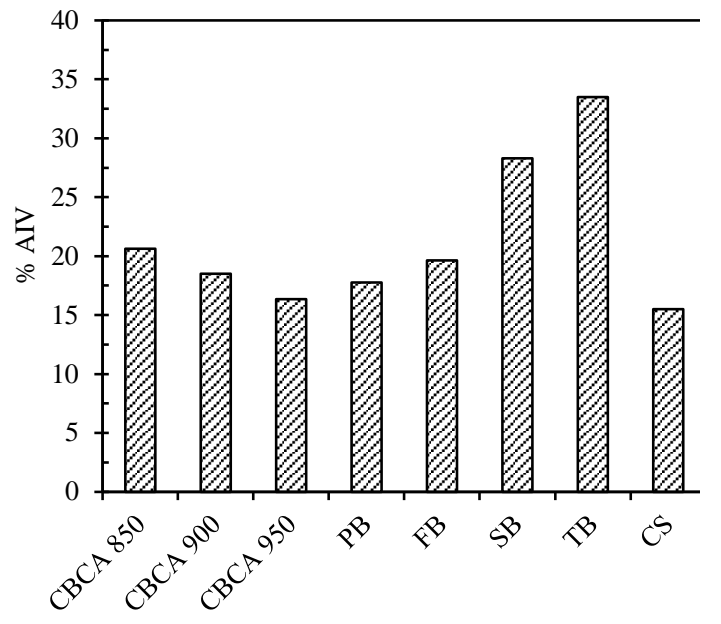

Fig. 6 Aggregate impact values of different types of coarse aggregates

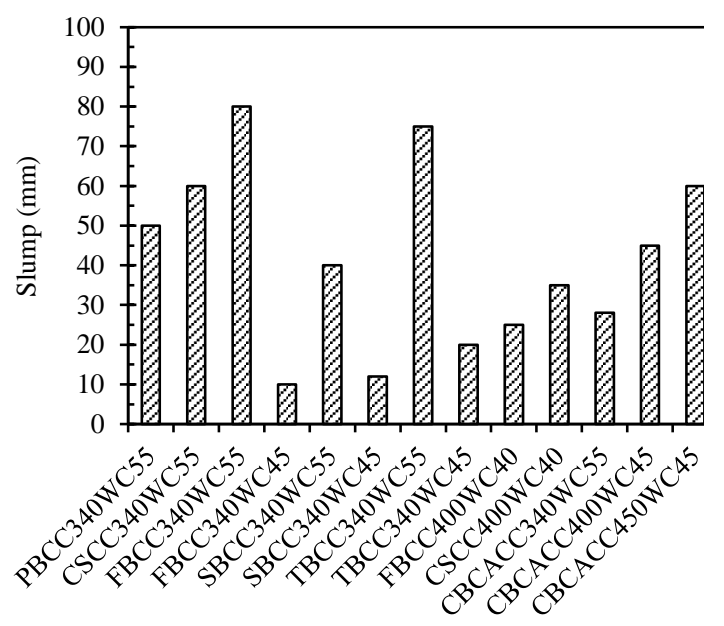

Fig. 8 Workability of fresh concrete

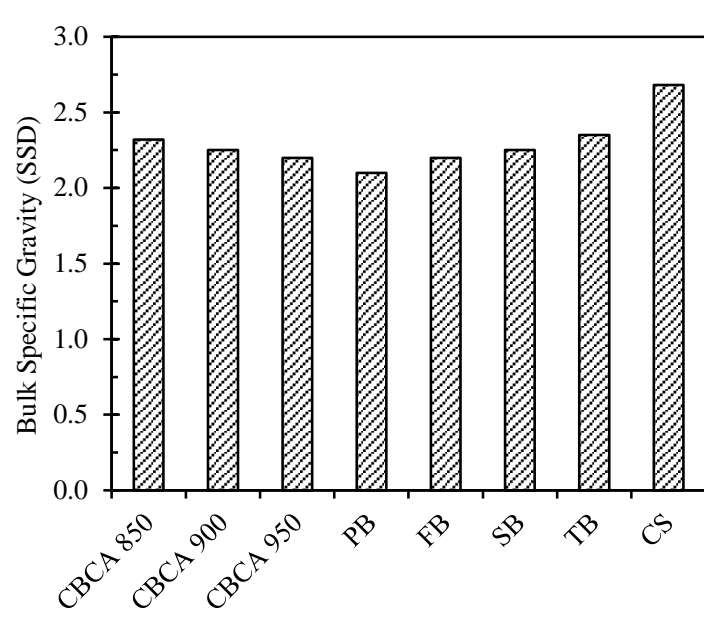

Fig.7 Bulk specific gravity (ssd) of different types of coarse aggregate

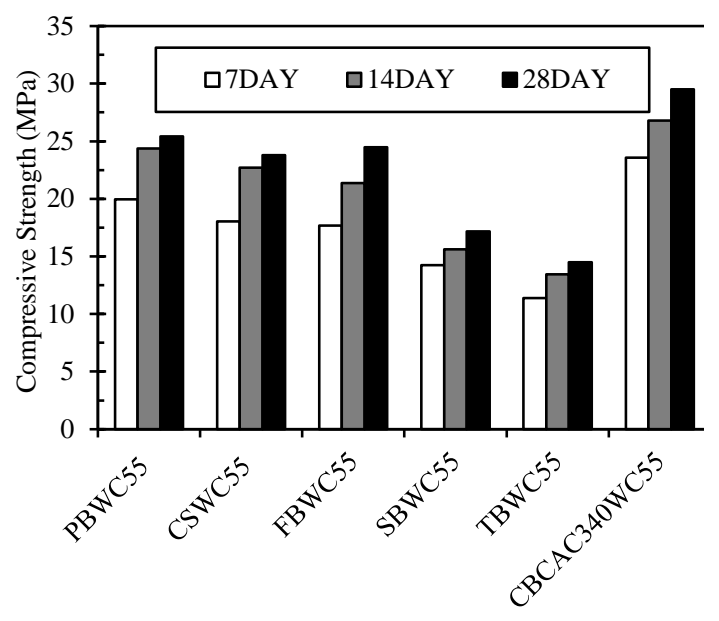

Fig. 9 Compressive strength of concrete $(\mathrm{W} / \mathrm{C}=0.55$, Cement content $=340$ $\mathrm{kg} / \mathrm{m}^{3}$ )

\section{Mechanical Properties of Concrete}

The compressive strength of concrete made with different aggregates is shown in Fig. 9 for $\mathrm{W} / \mathrm{C}=0.55$ and cement content $=340 \mathrm{~kg} / \mathrm{m}^{3}$. Irrespective of the age of concrete specimens, it is found that concrete made with CBCA gives higher strength compared to the other aggregates. CBCA gives more strength due to the proper gradation and cubical shape of the aggregates. Also it is expected that the interlocking of aggregates for $\mathrm{CBCA}$ is better compared to the other aggregates. 


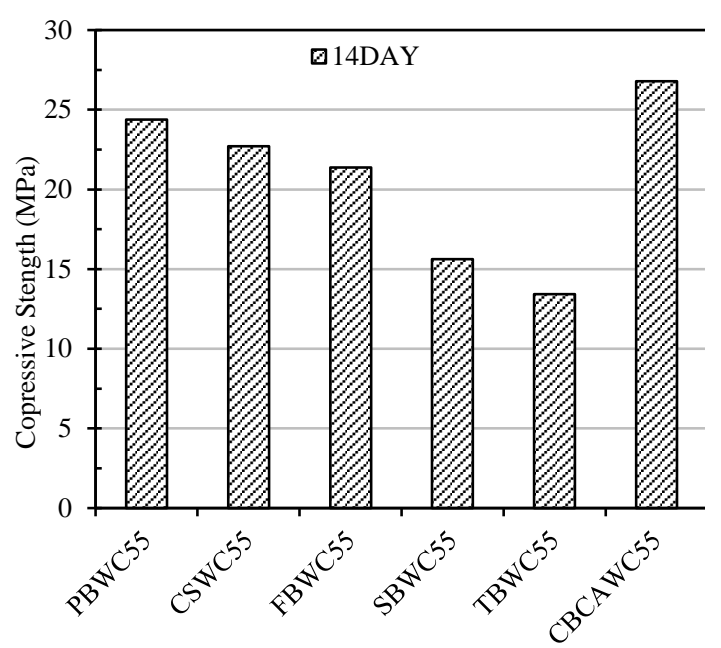

Fig. 10 Compressive strength of concrete with low W/C and high cement content

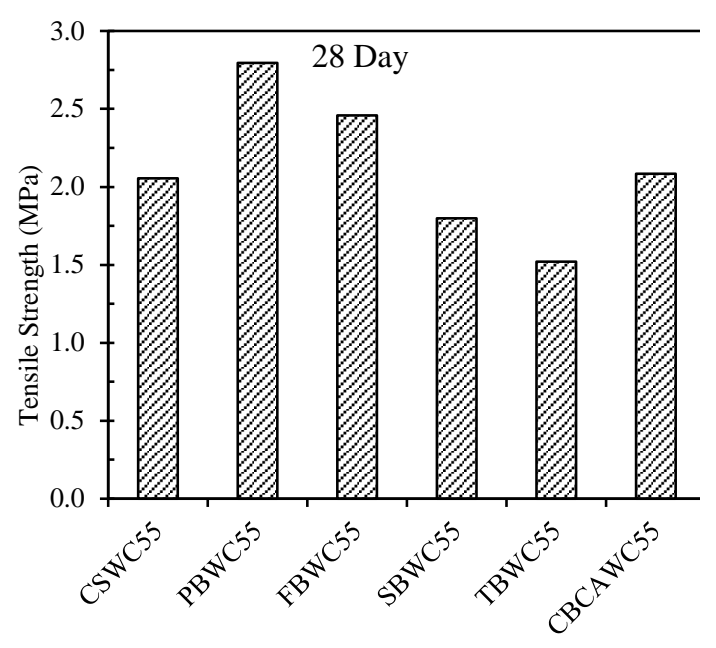

Fig. 11 Tensile strength of concrete made with $\mathrm{W} / \mathrm{C}=0.55$ and cement content $340 \mathrm{~kg} / \mathrm{m}^{3}$

Variation of compressive strength of concrete at 28 days for different aggregates at low and high W/C is shown in Fig. 10. The compressive strength of concrete made with CBCA is increased with the reduction of W/C and also with the increase of cement content. Compared to the FB and CS, CBCA also gives higher strength at low W/C and higher cement content. By using CBCA, it is possible to make 6000 psi concrete with $\mathrm{W} / \mathrm{C}=0.45$ and cement content $=450 \mathrm{~kg} / \mathrm{m}^{3}$.

The variation of tensile strength concrete for different aggregates is shown in Fig. 11. It is found that the tensile strength of concrete is lower for concrete made with CBCA compared to the concrete made with PB and FB. Further investigation is necessary to understand the reason behind this result. No significant difference in tensile strength of concrete is found for CBCA and CS.

The variation of tensile strength of concrete is shown in Figure 12 for different aggregates made with low and high W/C and higher cement content. With the increase of cement content, the tensile strength of concrete made with CBCA is increased. No significant difference in tensile strength is found for CBCA and CS, however it is observed that the tensile strength of concrete made with CBCA is slightly lower than concrete made with FB.

Typical stress-strain curves of CBCA concrete are shown in Figure 13 for W/C $=0.55$ and cement content of $340 \mathrm{~kg} / \mathrm{m}^{3}$. CBCA shows steeper stress-strain curve compared to FB, SB TB, and similar to PB, but flatter than CS. Stress-strain curves for the clayburnt coarse aggregate and normal aggregate with low $\mathrm{W} / \mathrm{C}$ ratio and high cement content is shown in Fig. 14. It is found that the clay-burnt coarse aggregate shows steeper stress-strain curves compared to all other aggregates. 

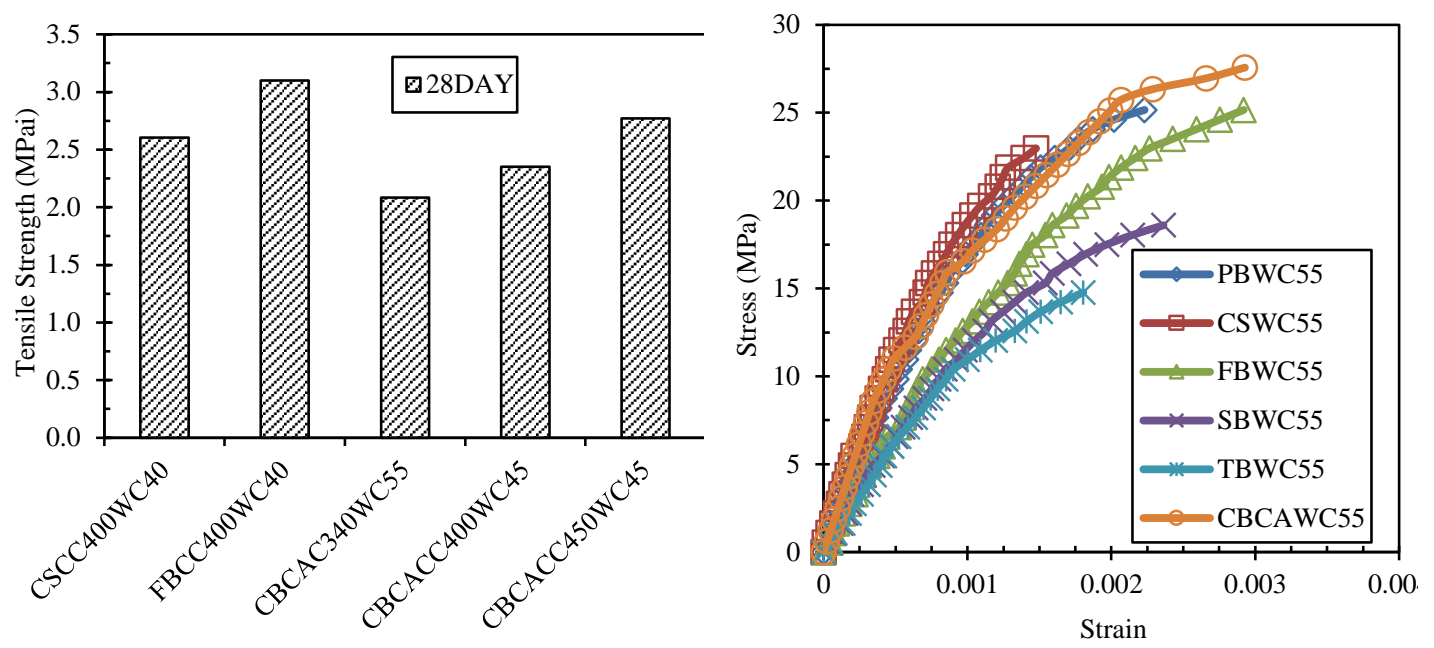

Fig. 12 Tensile strength of concrete with low W/C ratio and high cement content

Fig. 13 Stress-strain curves of concrete $(\mathrm{W} / \mathrm{C}=0.55$, cement content $=340$ $\mathrm{kg} / \mathrm{m}^{3}$ )
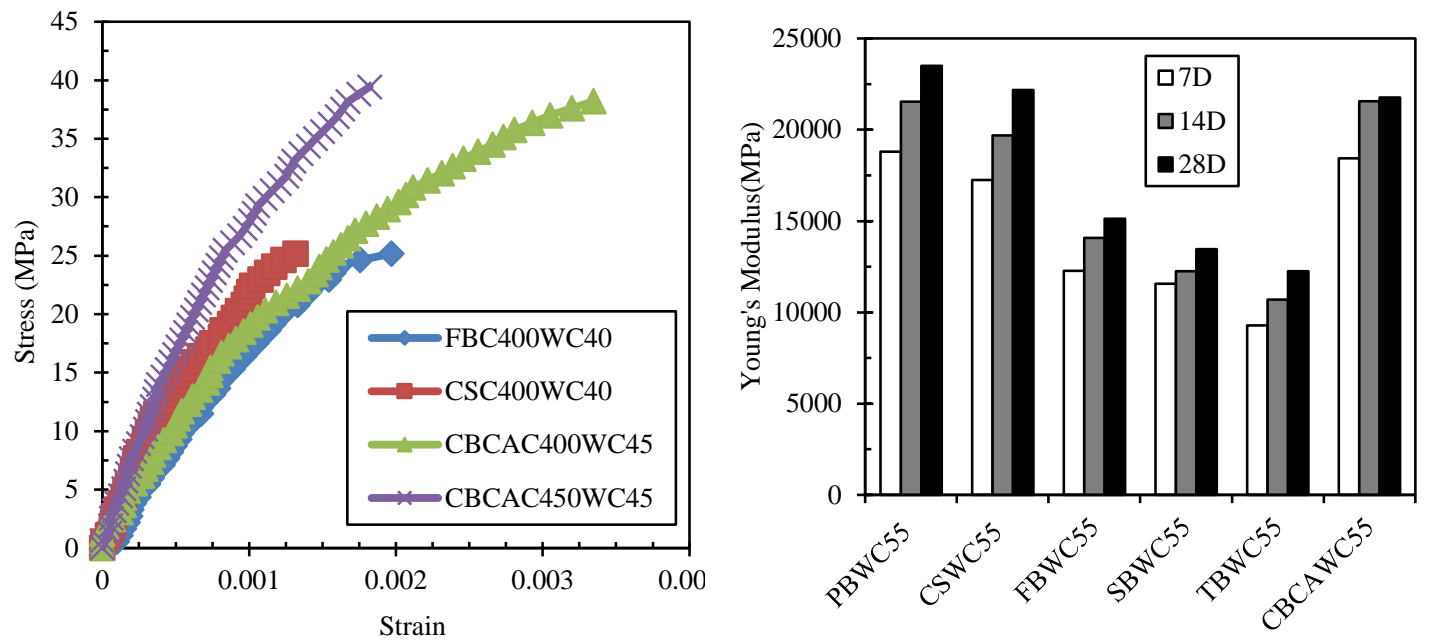

Fig. 14 Stress-strain curves of 28 day's concrete with high cement content and low $\mathrm{W} / \mathrm{C}$ ratio

Fig.15 Young's modulus of concrete $(\mathrm{W} / \mathrm{C}=0.55$, cement content $=340$ $\mathrm{kg} / \mathrm{m}^{3}$ )

Young modulus of concrete at different ages is shown in Fig. 15 for different aggregates for $\mathrm{W} / \mathrm{C}=0.55$ and cement content $=340 \mathrm{~kg} / \mathrm{m}^{3}$. Concrete made with CBCA shows higher Young's modulus compared to the same made with FB, but no significant difference is found for concrete made with $\mathrm{CBCA}, \mathrm{PB}$, and CS.

Young's modulus of concrete made with different aggregates at low W/C and higher cement content is shown in Fig. 16. Significant improvement of Young's modulus of 
concrete is found for CBCA. It is also found that with the increase of cement content the Young's modulus of concrete made with CBCA is increased.

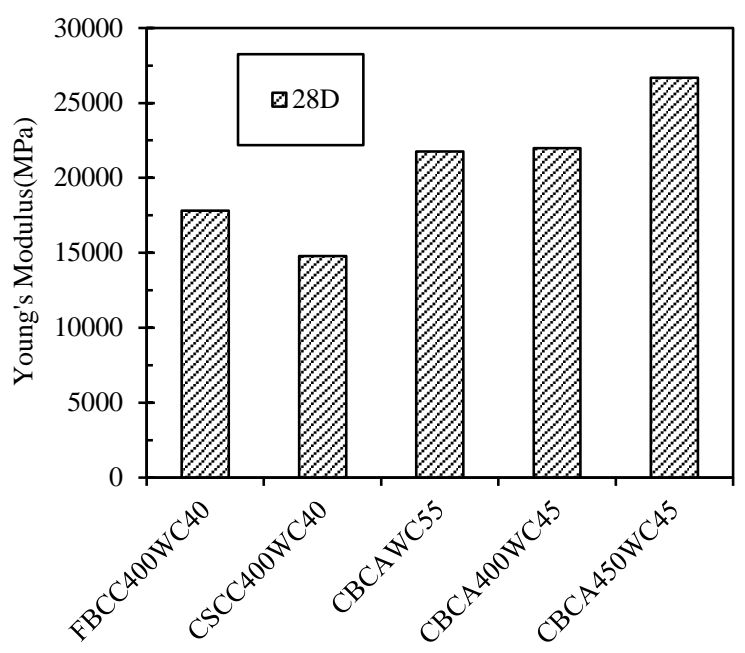

Fig. 16 Young's Modulus of 28 Day Concrete with High Cement Content and Low $\mathrm{W} / \mathrm{C}$

\section{CONCLUSIONS}

The following conclusions are made from this investigation on clay-burnt coarse aggregate (CBCA):

(1) It is possible to produce CBCA by burning directly,

(2) The quality of CBCA is improved with the increase of burning temperature $\left(850^{\circ} \mathrm{C}\right.$ to $950^{\circ} \mathrm{C}$ ),

(3) With the increase of burning temperature, the weight of CBCA is reduced,

(4) By using CBCA burnt at $950^{\circ} \mathrm{C}$, it is possible to produce 6000 psi concrete with $\mathrm{W} / \mathrm{C}=0.45$ and cement content $=450 \mathrm{~kg} / \mathrm{m}^{3}$, and

(5) Concrete made with CBCA shows lower tensile strength compared to the concrete made with traditional first class brick aggregate $(\mathrm{FB})$.

\section{ACKNOWLEDGMENT}

This study was conducted at the Department of Civil Engineering of University of Asia Pacific (UAP) by the first author during his stay at UAP. The author acknowledges the support of UAP to conduct this study. 


\section{REFERENCES}

ASTM C33 (2003). "Standard Specification for Concrete Aggregates", Annual Book of ASTM Standard, Denver.

CEMBUREAU (2008), “Activity report 2007”. The European Cement Association, Brussels. 44.

IDLC Finance Limited (2011), "Research Report: Cement Sector of Bangladesh", Bangladesh.

Mehta, P. K. (2009), "Global Concrete Industry Sustainability”,ACI Concrete International, 45-48.

Mohammed, T. U., Hasnat, A., Sarwar, N., Das, H. K., Miah, J. M., Awal, M. A. (2011),"Sustainable Development of Construction Works in Bangladesh", Proceedings of 3rd EACEF International Conference, Indonesia,271-277.

Mohammed, T. U., Hasnat, A., Awal, M. A., Bosunia, S. Z. (2015). "Recycling of Brick Aggregate Concrete as Coarse Aggregate", Journal of Materials in Civil Engineering, Vol. 27, No. 7, July 2015 (doi: http://dx.doi.org/10.1061/(ASCE)MT.1943-5533.0001043).

U.S. Department of Transportation Federal Highway Administration (2004),"Transportation Applications of Recycled Concrete Aggregate", FHWA State of the Practice National Review, Washington DC, USA, 1-47. 